\title{
CHEMICAL EVIDENCE SUPPORTING THE ICLUSION OF AMARANTHACEAE AND CHENOPODIACEAE INTO ONE FAMILY AMARANTHACEAE JUSS. (s.l.)
}

\author{
Fatima Mubark ${ }^{1}$ \\ ${ }^{1}$ PhD Research Scholar, Medicinal and Aromatic Plants research Institute, \\ National Council for Research, Khartom, Sudan
}

\author{
Ikram Madani Ahmed ${ }^{2}$ \\ ${ }^{2}$ Associate Professor, Department of Botany, Faculty of Science, University of Khartoum, \\ Sudan
}

Corresponding author: Ikram Madani,

Article DOI: https://doi.org/10.36713/epra6001

\begin{abstract}
In this study, separation of chemical compounds using Thin layer chromatography technique revealed close relationship between the studied members of the newly constructed family Amaranthaceae Juss. (s.l.). 68\% of the calculated affinities between the studied species are above $50 \%$ which is an indication for close relationships. $90 \%$ is the chemical affinities reported between Chenopodium murale and three species of the genus Amaranthus despite of their great morphological diversity. Among the selected members of the chenopodiaceae, Chenopodium murale and Suaeda monoica are the most closely related species to all of the studied Amaranthaceae . 60\%-88\% and 54\%-88\% chemical affinities were reported for the two species with the Amaranthaceae members respectively. GC-Mass analysis of methanolic extracts of the studied species identified 20 compounds common between different species. 9,12Octadecadienoic acid (Z,Z)-,2-hydroxy-1 and 7-Hexadecenal, $(Z)$ - are the major components common between Amaranthus graecizans, Digera muricata Aerva javanica Gomphrena celosioides of the historical family Amaranthaceae and Suaeda monoica Salsola vermiculata Chenopodium murale Cornulaca monocantha of the historical family Chenopodiaceae, Most of the identified compounds are of pharmaceutical importance such as antioxidants, anti-inflammatory, and Anti-cancerous.
\end{abstract}

KEYWORDS: Chemical affinity; TLC; GC- Mass analysis; Amarancaceae; Chenopodiaceae

\section{INTRODUCTION}

The Chenopodiaceae and Amaranthaceae are morphologically related families of the order Caryophyllales. Plants of these families are characterized by free-central or basal placentation, curved embryos, presence of perisperm, beaked integuments, distinctive phloem plastid morphology, and betalain pigmentation (Judd et al., 2002). Amaranthaceae, and Chenopodiaceae were historically grouped by Bentham and Hooker (1880) in one subclass Monochlamydeaes based on their panporate pollen grains while Engler and Prantl $(1887 ; 1898)$ grouped these families in Archichlamydeae based on some similar petals characters. Hutchinson (1926; 


\section{EPRA International Journal of Research and Development (IJRD)}

1959) placed Amaranthaceae, and Chenopodiaceae in the herbaceous group ,the 'Herbaceae'; under the Order Chenopodiales. Takhtajan (1969) kept Amaranthaceae and Chenopodiaceae under Class Magnoliatae, Subclass Caryophyllidae and Super order Caryophyllanae in Order Caryophyllales.

Metcalfe and Chalk (1950) while reviewing the anatomical characters of these families and their taxonomic and phylogenetic positions reported that the Amaranthaceae and the Chenopodiaceae are alike in exhibiting similar anomalous secondary thickening. Similarities between these two families has been confirmed by molecular analysis (Manhart and Rettig 1994; Downie and Palmer 1994; Downie et al. 1997; Cuénoud et al. 2002). Recent molecular phylogenetic research strongly suggests the inclusion of Chenopodiaceae in Amaranthaceae to form the extended family Amaranceaceae which contains 10 subfamilies, 180 genera, and approximately 2,500 species (APGII, 2003, APGIII, 2009) .

In Sudan, Amaranthaceae is represented by 16 genera which are separately treated by Andrews (1952) as genera of the historical Amaranthaceae and Chenopodiaceae. Many species were reported as weeds of central Sudan (Braun et al., 1991) and common species in northern Sudan (Bebawi and Neugebbohrn, 1991). Recently,( Darbyshire et al., 2015) adopted the molecular classification of the extended family Amaranthaceae and reported their updated names in the annotated checklist for plants of Sudan and South Sudan.

The aim of this paper is to evaluate the significance of biochemical affinities between twelve selected species from the historical families Amaranthaceae and Chenopodiaceae which are recently grouped into one family Amaranthaceae Juss. (s.l.).

\section{MATERIALS AND METHODS}

Twelve plant species belonging to eight genera from the family Amaranthaceae Juss. (s.l.) were selected for this study. They were collected from their natural habitats in Sudan. These are Amaranthus viridis, Amaranthus graecizans, Amaranthus spinosus, Amaranthus blitum, Digera muricata, Aerva javanica, Gomphrena celosioides from the historical family Amaranthaceae and Suaeda monoica, Salsola imbricate, Salsola vermiculata, Chenopodium murale, and Cornulaca monocantha from the historical family Chenopodiaceae. Three grams of dried leaves of each plant were extracted with aqueous methanol and kept for $24 \mathrm{hr}$ in order to get concentrated extract. Three drops of the extracts were used for separation of compounds using Thin layer Chromatography (TLC ) technique in which ethyle acetate-formic acid-glacial acetic acid-water (100:11:11:26) solvents system was used. Retention factors $\left(\mathrm{R}_{\mathrm{f}}\right)$ values of the separated compounds were calculated. Biochemical affinities (PA) between the different species were calculated from the TLC plate following the method adopted by Ellison et al. (1962) as the ratio of the number of spots common in each pair of species to the total number of spots separated for the same pair. Three concentrated common spots were separately collected from the TLC plate using a spatula. Each spot was extracted with methanol and filtered to remove the silica. Extracts were subjected to Gas Chromatography and Mass Spectroscopy (GC-MS) analysis for the determination of bioactive volatile compounds. GCMS analysis of the samples was carried out using Shimadzu Make QP-2010 with non-polar 60 M RTX $5 \mathrm{MS}$ Column. Helium was used as the carrier gas and the temperature programming was set with initial oven temperature at $40^{\circ} \mathrm{C}$ and held for $3 \mathrm{~min}$ and the final temperature of the oven was $480^{\circ} \mathrm{C}$ with rate at $100 \mathrm{C}$ [min.sup.1]. 2- $\mu \mathrm{L}$ samples were injected with split less mode. Mass spectra were recorded over 35 - 650 amu range with electron impact ionization energy 70 $\mathrm{eV}$. The chemical components were identified by comparing the retention times of chromatographic peaks using Quadra pole detector with NIST Library to relative retention indices. Quantitative determinations were made by relating respective peak areas to TIC areas from the GC-MS.

\section{RESULTS}

Screening for compounds using TLC technique, resulted in many spots of different Retention Factor (Rf) values (plate1). Percentage of the paired affinity (PA) based on separated compounds are presented in (table1). $68 \%$ of the calculated affinities between the studied species are above $50 \%$. The highest PA values (77\% -90\%) was recorded between Chenopodium murale and the Amaranthaceae species. $60 \%-88 \%$ and $54 \%-88 \%$ chemical affinities were reported between Suaeda monoica and the Amaranthaceae species respectively. 


\section{EPRA International Journal of Research and Development (IJRD)}

Volume: 5 | Issue: 12 | December 2020

- Peer Reviewed Journal

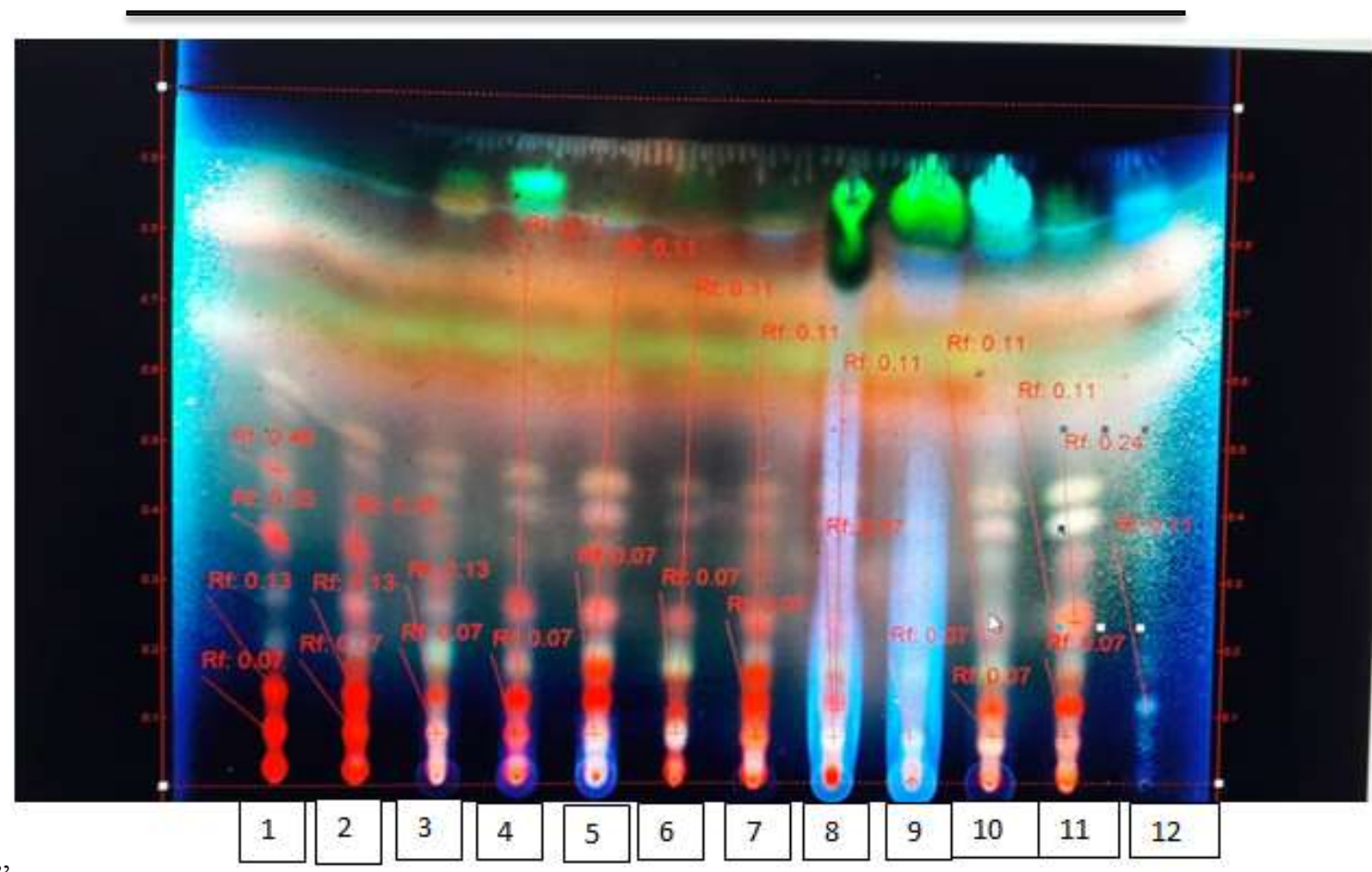

Plate 1. TLC chromatogram of methanolic extract of leaves of the studied species: (1) Amaranthus viridis (2) Amaranthus graecizans (3)Amaranthus spinosus (4)Amaranthus blitum (5) Digera muricata (6) Aerva javanica (7) Gomphrena celosioides (8) Suaeda monoica (9) Salsola imbricate(10) Salsola vermiculata (11) Chenopodium murale (12) Cornulaca monocantha

Table1. Percentage of the paired affinity (PA) based on all of the compounds separated on TLC for the studied species

\begin{tabular}{|c|c|c|c|c|c|c|c|c|c|c|c|c|}
\hline \multirow{2}{*}{ Species } & \multicolumn{10}{|c|}{ \%age paired affinities } \\
\cline { 2 - 13 } & $\mathbf{1}$ & $\mathbf{2}$ & $\mathbf{3}$ & $\mathbf{4}$ & $\mathbf{5}$ & $\mathbf{6}$ & $\mathbf{7}$ & $\mathbf{8}$ & $\mathbf{9}$ & $\mathbf{1 0}$ & $\mathbf{1 1}$ & $\mathbf{1 2}$ \\
\hline $\mathbf{1}$ & 100 & 86 & 55 & 40 & 55 & 40 & 75 & 72 & 44 & 54 & 77 & 42 \\
\hline $\mathbf{2}$ & & 100 & 45 & 36 & 50 & 66 & 54 & 60 & 57 & 63 & 90 & 50 \\
\hline $\mathbf{3}$ & & & 100 & 55 & 66 & 44 & 66 & 77 & 44 & 72 & 80 & 44 \\
\hline $\mathbf{4}$ & & & & 100 & 86 & 86 & 87 & 87 & 57 & 88 & 88 & 50 \\
\hline $\mathbf{5}$ & & & & & 100 & 66 & 77 & 88 & 37 & 80 & 90 & 44 \\
\hline $\mathbf{6}$ & & & & & & 100 & 87 & 87 & 57 & 77 & 88 & 44 \\
\hline $\mathbf{7}$ & & & & & & & 100 & 88 & 62 & 72 & 90 & 44 \\
\hline $\boldsymbol{8}$ & & & & & & & & 100 & 80 & 50 & 62 & 80 \\
\hline
\end{tabular}

2020 EPRA IJRD | Journal DOI: https://doi.org/10.36713/epra2016 |www.eprajournals.com |273 | 


\section{EPRA International Journal of Research and Development (IJRD)}

\begin{tabular}{|c|l|l|l|l|l|l|l|l|l|l|l|l|}
\hline $\mathbf{9}$ & & & & & & & & & 100 & 37 & 25 & 50 \\
\hline 10 & & & & & & & & & & 100 & 97 & 28 \\
\hline 11 & & & & & & & & & & & 100 & 42 \\
\hline 12 & & & & & & & & & & & & 100 \\
\hline
\end{tabular}

Key to the species: (1) Amaranthus blitum (2) Amaranthus viridis (3) Digera muricata (4) Aerva javanica (5) Amaranthus graecizans (6) Gomphrena celosioides (7) Amaranthus spinosus (8) Suaeda monoica (9) Salsola imbricate (10) Salsola vermiculata (11) Chenopodium murale (12) Cornulaca monocantha

Table 2 shows common concentrated spots separated from extracts of different plants. Gc-Mass analysis of the common spots identified 20 organic compounds. GC-Mass chromatograms of the detected compounds were represented in figures 1, 2, and 3 . Aerva javanica, Amaranthus graecizans, Gomphrena celosioides, Digera muricata, Suaeda monoica, Salsola vermiculata., Chenopodium album, and Cornulaca monocantha have a common spot of $\mathrm{Rf}$ value 0.011 . GC-mass analysis of this spot identified nine compounds of which 9,12-Octadecadienoic acid (Z,Z)- ,2-hydroxy-1 and 7-Hexadecenal,(Z)- are the major components. 3-Cyclohexen-1-ol, 1-methyl-4-(1methylethyl) represents the major component identified for the spot of the $\mathrm{Rf}$ value 0.13 which is separated for Amaranthus blitum. , Amaranthus viridis, and Amaranthus spinosus. The spot of $\mathrm{Rf}$ value 0.35 is reported for both Amaranthus blitum and Amaranthus viridis 4-Hydroxy-2-methylbenzaldehyde represents the majoir component of this spot which contains 8 other compounds.

Table1. Concentrated spots selected for GC-Mass analysis

\begin{tabular}{|l|c|c|c|}
\hline \multirow{2}{*}{ Plant species } & \multicolumn{2}{|c|}{$\mathbf{R}_{\mathbf{f}}$ values of the separated compounds } \\
\cline { 2 - 4 } & 0.11 & 0.13 & 0.35 \\
\hline Amaranthus blitum & - & + & + \\
\hline Amaranthus viridis & - & + & + \\
\hline Amaranthus spinosus & - & + & - \\
\hline Amaranthus graecizans & + & - & - \\
\hline Digera muricata & + & - & - \\
\hline Aerva javanica & + & - & - \\
\hline Gomphrena celosioides & + & - & - \\
\hline Suaeda monoica & + & - & - \\
\hline Salsola imbricata & - & - & - \\
\hline Salsola vermiculata & + & - & - \\
\hline Chenopodium murale & + & - & - \\
\hline Cornulaca monocantha & + & - & - \\
\hline
\end{tabular}




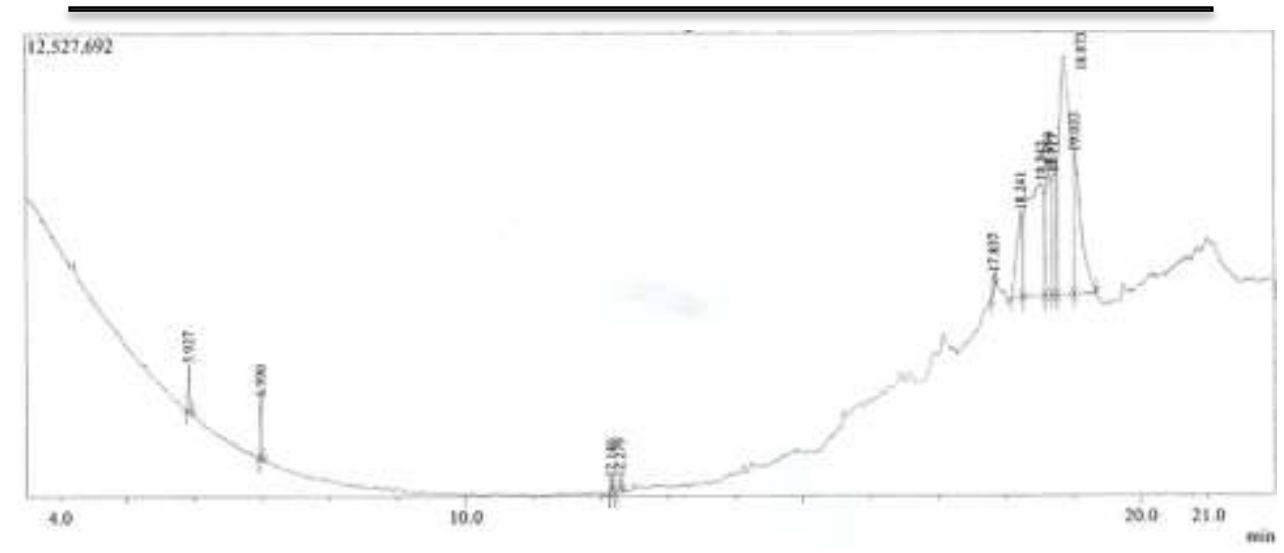

Figure 1. GC-MS chromatogram of Phytoconstituents obtained from spot Rf value 0.11

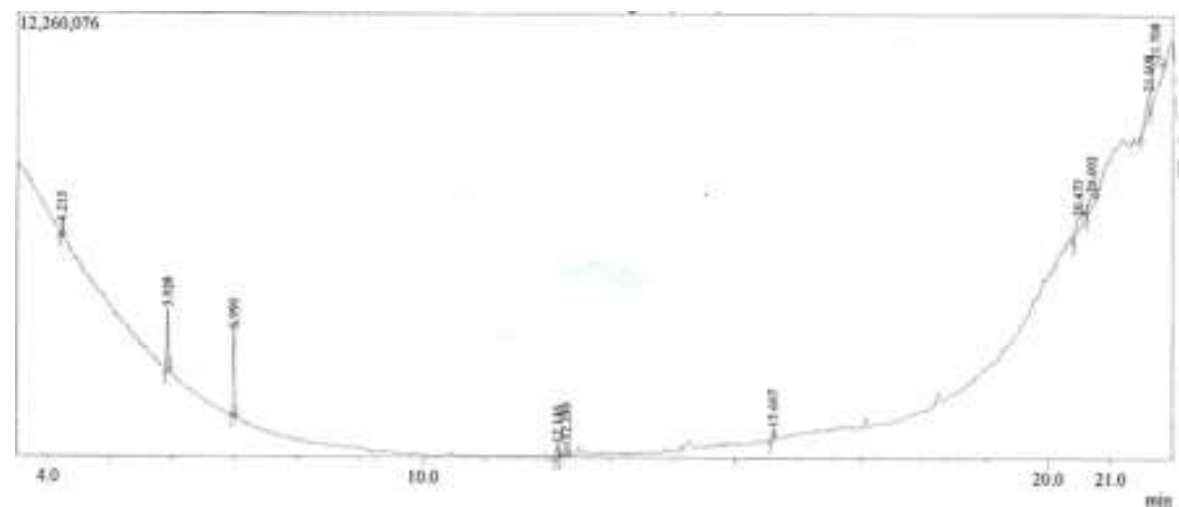

Figure 2. GC-MS chromatogram of Phytoconstituents obtained from spot Rf value 0.13

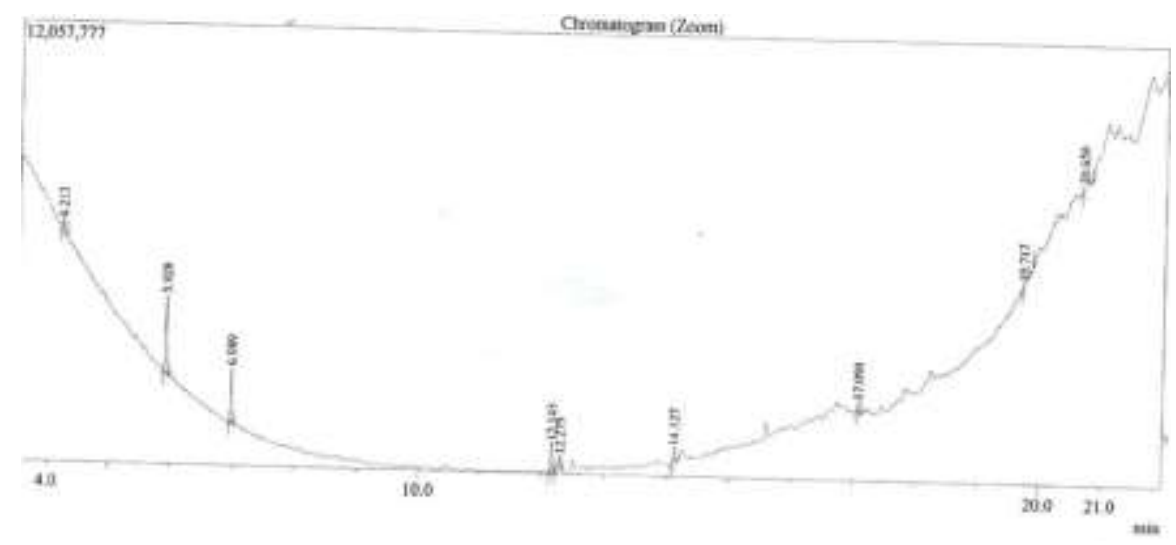

Figure 3. GC-MS chromatogram of Phytoconstituents obtained from spot Rf value 0.35 


\section{EPRA International Journal of Research and Development (IJRD)}

Table3. Phytochemical constituents identified for the studied species

\begin{tabular}{|l|l|l|l|}
\hline Rf values & \multicolumn{1}{|c|}{ Identified compounds } & R.Time & Area\% \\
\hline 0.11 & Benzaldehyde,4-methoxy- & 5.927 & 0.93 \\
& 3,4-Dimethoxyphenylacetone & 6.990 & 1.14 \\
& Hexadecanoic acid,methyl ester & 12.146 & 0.31 \\
& 7,9-Di-tert-butyl-1-oxaspiro(4,5)deca-6,9-dien & 12.279 & 0.36 \\
& 7-Hexadecenoic acid,methyl ester,(Z)- & 17.837 & 0.55 \\
& Di-n-octyl phthalate & 18.241 & 6.31 \\
& 7-Hexadecenal,(Z)- & 18.542 & 25.31 \\
& Octadecanoic acid,1-\{\{(1-oxohexadecyl)oxy\}r & 18.717 & 7.06 \\
& 9,12-Octadecadienoic acid (Z,Z)-,2-hydroxy-1 & 18.873 & 35.71 \\
\hline 0.13 & & & \\
& Benzaldehyde, 4-methoxy- & 5.928 & 10.50 \\
& Benzeneacetic acid, 3,4-dimethoxy-, methyl es & 6.990 & 12.88 \\
& Hexadecanoic acid, methyl ester & 12.146 & 2.56 \\
& 7,9-Di-tert-butyl-1-oxaspiro(4,5)deca-6,9-dien & 12.280 & 3.35 \\
& Azacyclotridecan-2-one & 15.607 & 2.65 \\
& Patchouli alcohol & 20.692 & 13.80 \\
& 6-Octen-1-ol,3,7-dimethyl-,propanoate & 21.608 & 11.05 \\
& 3-Cyclohexen-1-ol, 1-methyl-4-(1-methylethyl) & 21.708 & 32.02 \\
& & & \\
\hline 0.35 & Undecane & 4.213 & 4.10 \\
& 4-Hydroxy-2-methylbenzaldehyde & 5.928 & 29.45 \\
& Benzeneacetic acid, 3,4-dimethoxy-,methyl es & 6.989 & 19.15 \\
& Hexadecanoic acid, methyl ester & 12.145 & 13.10 \\
& Butylated Hydroxytoluene & 12.279 & 6.07 \\
& Methyl stearate & 14.127 & 7.67 \\
& Phenol,2,2-methylenebis\{6-(1,1-dimethylethy & 17.090 & 4.99 \\
& Linoleic acid ethyl ester & 19.717 & 5.66 \\
& & & \\
\hline
\end{tabular}

\section{DISCUSSION}

In this study, identification of nine phytochemical compounds common between Amaranthus graecizans, Digera muricata Aerva javanica Gomphrena celosioides of the historical family Amaranthaceae and Suaeda monoica Salsola vermiculata Chenopodium murale Cornulaca monocantha of the historical family Chenopodiaceae, supports the new inclusion of the two families by the APG III ( APG, ) into a new broadened family Amaranthaceae Juss. (s.l.). According to Ellison et al. (1962) PA values of 50\% and above are considered as marker of close relationship. The results revealed $90 \%$ chemical affinities between Chenopodium murale and three species of the genus Amaranthus despite of their great morphological diversity. Among the selected members of the chenopodiaceae, Chenopodium murale and Suaeda monoica are the most closely related species to all of the studied Amaranthaceae . 60\%-88\% and $54 \%-88 \%$ chemical affinities were reported for the two species with the Amaranthaceae members respectively. Most of the identified compounds are of pharmaceutical importance. Phenol,2,2methylenebis $\{6$-(1,1-dimethylethy), 7,9-Di-tert-butyl1-oxaspiro(4,5) deca-6,9-dien, Butylated Hydroxytoluene, and 3-Cyclohexen-1-ol, 1-methyl-4(1-methylethyl) reported by many authors as antioxidants (Hema et al, 2011; Sudharsan et al, 2010; Naher et al, 2013). Hexadecanoic acid, methyl ester, Linoleic acid ethyl ester, Hexadecanoic acid, methyl ester, 3-Cyclohexen-1-ol, and 1-methyl-4-(1methylethyl) reported as anti-inflammatory (Hema et al, 2011; Naher et al, 2013; Othman et al, 2015; Sudha et al, 2013 ). Benzaldehyde, 4-methoxy, Methyl stearate, Butylated Hydroxytoluene, 7Hexadecenal,(Z)-, and 3-Cyclohexen-1-ol, 1-methyl-4(1-methylethyl) considered as Anti-cancerous as reported by Kundu and Metra (2016), Naher et al (2013), Ukwubile et al (2019), Hamid et al, (2017). Antibacterial activity of the Patchouli alcohol3Cyclohexen-1-ol, 1-methyl-4-(1-methylethyl) 7Hexadecenoic acid,methyl ester,(Z)- Di-n-octyl 


\section{SJIF Impact Factor: 7.001| ISI I.F.Value:1.241| Journal DOI: 10.36713/epra2016 ISSN: 2455-7838(Online) EPRA International Journal of Research and Development (IJRD)}

phthalate

Octadecanoic

acid, $1-\{\{(1-$

oxohexadecyl)oxy $\} r$, and Di-n-octyl phthalate has been reported by Bunrathep et al, (2006), Naher et al, (2013), Krishnaveni et al., (2014). Kale ,(2015) and Jabeen , (2018).

\section{REFERENCES}

1. Judd, W. S., C. S. Campbell, E. A. Kellogg, and P. F. Stevens. 2002. Amaranthaceae. PP. 245-246 in Plant Systematics: A Phytogenetic Approach. Sinauer Associates, Inc. Massachusetts, USA.

2. Bentham, G. and Hooker, J.D. (1880): Genera Plantarum, 3. Reeve and Co., Ltd. Kent.

3. Engler, A. and Prantl, R. (1887).die Naturlichen Pflanzenfamilien,Leipzig.

4. Hutchinson, J. 1926: The Families of Flowering Plants, Vol. I, Oxford University Press, Oxford.

5. Takhtajan, A. 1969 : Flowering Plants : Origin and Dispersal, Transl. by C. Jeffrey Oliver \& Boyd., Edinburgh.

6. Metcalfe and Chalk (1950)

7. Manhart, J. R. and J. H. Rettig. 1994. Gene sequence data. Pp. 235-246 in Caryophyllales evolution and systematics, eds. Behnke, H. D. and T. J. Mabry. Springer-Verlag.

8. Downie, SR. and J.D. Palmer. (1994). A chloroplast DNA phytogeny of the Caryophyllales based on structural and inverted repeat restriction site variation. Systematic Botany 19: 236-252.

9. Downie, S. R., D. S. Katz-Downie, and K. J. Cho. (1997). Relationships in the Caryophyllales as suggested by phylogenetic analysis of partial chloroplast ORF 2280 homolog sequences. American Journal of Botany 84: 253-273.

10. Cuénoud, P., V. Savolainen, L.W. Chatrou, M. Powell, R.J. Grayer, and M.W. Chase. (2002). Molecular phylogenetics of Caryophyllales based on nuclear $18 S$ rDNA and plastid rbcL, atpB, and matK DNA sequences. American Journal of Botany 89:132-144.

11. Angiosperm Phylogeny Group II .2003. An update of the Angiosperm Phylogeny Group classification for the orders and families of flowering plants: APG II., Botanical Journal of the Linnean Society 141: 399-436.

12. Angiosperm Phylogeny Group III .2009. An update of the Angiosperm Phylogeny Group classification for the orders and families of flowering plants: APG III. Botanical Journal of the Linnean Society 161 (2): 105-121.

13. Andrews, F.W.1952. The Flowering Plants of the Sudan. Vol. I. T. Buncle and Co. Ltd. Arboath, Scptland.Vol. II: 109-122.

14. Braun, M.H., Burgstaller, A.M. Hamdoun and H. Walter (1991). Common weeds of central Sudan. GTZ.
15. Bebawi, F.F. and Neugebbohrn, L. (1991). A review of plants of Northern Sudan, with special references to their uses. GTZ. Eschborn.

16. Darbyshire, I., Kordofani, M., Imadeldin, F. and Pickering, H. 2015. The plants of Sudan and South Sudan. An annotated checklist. Kew Publishing, Roy. Bot. Gard., Kew: 275-280.

17. Ellison, W.L., Alston, R.E. and Turner, B.L., 1962. Methods of presentation of crude biochemical data for systematic purposes with particular reference to the genus Bahia (Compositae). Am. J. Bot. 49: 599604.

18. Hema R., S. Kumaravel and $K$. Alagusundaram.2011. GC/MS Determination of Bioactive Components of Murraya koenigii. Journal of American Science ;7(1):80-83.

19. Sudharsan $S$, Saravanan $R$, Shanmugam $A$, Vairamani S, Kumar RM, Menaga S, et al. Isolation and characterization of octadecanoic acid from the ethyl acetate root extract of Trigonella foneumgraecum L. by using hydroponics method. J Bioterror Biodef 2010;2:105

20. Naher S. , Alam M. , Rahman Md. and Aziz Sh.2013. Comparative studies on physic-chemical properties and GC-MS analysis of essential oil of Myristica fragrans , ISSN 2224-1698 Jagannath University Journal of Science, Volume-2, Number-I.

21. Othman A.R.,Abdullah N.,Ahmed S.,Ismail S. \& Zakaria M.2015, Elucidation of in-vitro antiinflammatory bioactive compounds isolated from Jatropha curcas L. plant root,New journal series.

22. Sudha T, Chidambarampillai $S$ and Mohan V.R.2013. GC-MS Analysis of Bioactive Components of Aerial parts of Fluggea leucopyrus Willd. (Euphorbiaceae), Journal of Applied Pharmaceutical ScienceVol. 3(05), pp. 126-130.

23. Kudu A. \& Mirta A.2016.Methoxybenzaldhydes in plants,insight nature resources, isolation, application and biosynthesis.Current science, Vol.111,No.8.

24. C.A. Ukwubile,A. Ahmed,U.A. Katsayal .2019. GC$M S$ analysis of bioactive compounds from Melastomastrum capitatum (Vahl) Fern. leaf methanol extract: An anticancer plant,Scientific African, Volume 3.

25. Hamid, A. A., Aliyu, M. A., Abubakar, L. Z., Mukadam et al.2017.Thaumatococcus daniellii leaves :Its chemical compositions,antioxidant and antimicrobial activities, Journal of Science (2017)vol. 19, no. 2.

26. Bunrathep S., Lockwood G., Songsak T. and Ruangrungsi N.2006. Chemical Constituents from Leaves and Cell Culturesof Pogostemon cablin and Use of Precursor Feeding toImprove Patchouli Alcohol Level, ScienceAsia 32 : 293-296.

27. Krishnaiah D.,Sarbatly R.,Nythianandum R.,2011.A review of the antioxidant potential of 


\section{EPRA International Journal of Research and Development (IJRD)}

medicinal plant species,food bioproducts

processing, Volume 89, Issue 3, Pages 217-233.

28. Kale V. M. 2015.GC-MS analysis of phytocomponents on whole plant extract Adiantum capillus-veneris $L$. A potential folklore medicinal plant .Life Science Informatics Publications, DOI $10.26479 / 0102.06$.

29. Jabeen K., Asad S. and Zakria M., 2018.Antifungal Evaluation and Phytochemical Identification of Selected Botanicals against Ceratocystis manginecans Causing Mango Sudden Death, Plant Pathol Microbiol, 9:11. 